\title{
An Empirical Approach to Get the Vitality of a Genotype to Water Stress Tolerance in Yield and Yield Contributing Traits
}

\author{
Ijaz Rasool Noorka ${ }^{1^{*}}$, Saba Tabasum ${ }^{2}$ \\ ${ }^{1}$ Department of Plant Breeding and Genetics, University College of Agriculture, University of Sargodha, Sargodha, Pakistan; ${ }^{2}$ Mo- \\ lecular and Cytogenetics Lab, University of Leicester, Leicester, UK. \\ Email: *ijazphd@yahoo.com
}

Received April $2^{\text {nd }}, 2013$; revised May $1^{\text {st }}, 2013$; accepted May $16^{\text {th }}, 2013$

Copyright (C) 2013 Ijaz Rasool Noorka, Saba Tabasum. This is an open access article distributed under the Creative Commons Attribution License, which permits unrestricted use, distribution, and reproduction in any medium, provided the original work is properly cited.

\begin{abstract}
Conventional methods of plant breeding and agronomic practices remained a successful tool to maintain the pace of food production for centuries but due to changing climatic conditions and the challenges of $21^{\text {st }}$ century like population growth, pollution, declining biodiversity and food security have shaken the previous policies. This situation compelled the agriculturist towards the judicious management of natural resources to combat the poverty, disasters and increased food demands. The present study was initiated to check wheat varieties in two water provision conditions. The results revealed that environmental stresses played negative role by minimizing the yield and yield contributing traits. However the severity of water stress was depleted by some promising genotypes by showing minimum hazard effects and by having capability to contribute to conserving biodiversity, ensuring sustainability, combating food insecurity and increasing economic benefits. The minimum effect of moisture stress on grain yield was shown by genotypes C-518 (12.97\%) while the genotype Shakar, Pari-73 and Uqab-2000 showed maximum decline percentage. The global warming and population explosion will further induce commodity shortage and law and order situation in the world. The prevailing International tension can be cooled down by the provision of marshal aids by the developed countries to the effected or threatened countries.
\end{abstract}

Keywords: Climate; Disaster; Water Stress; Poverty; Sustainable; Wheat

\section{Introduction}

Food security is a human right through the globe. The pressure on fundamental natural resources, i.e. land, water and labor witnessed last century in shrinkage of food, fiber and fuel which will continue in the current century due to burgeoning population [1]. Food security situation in developing countries is crippling persistently due to rough farming, economic, financial and water stresses [2]. Pakistan's economy is fully dependent on agriculture and depicted itself as the biggest employer.

The graph in next page presents twenty most important food and agricultural commodities (ranked by value) production in Pakistan [3]. Food security exists when all people, at all times, have physical, social and economic access to sufficient, safe and nutritious food which meets

*Corresponding author. peoples dietary needs and food preferences for an active and healthy life [3].

In 1996 the World Food Summit (WFS) set the target of "eradicating hunger in all countries, with an immediate view to reducing the number of undernourished people to half their present level no later than 2015”. In 2000, the Millennium Declaration (MD) promoted the target to "halve, between 1990 and 2015, the proportion of people who suffer from hunger" [3].

Conventional agriculture techniques remained a successful tool to maintain the pace of food production for centuries. In Pakistan from its existence most of agricultural varietal development work was done to increase yield by the use of minimum water $[4,5]$. Plant breeder's inputs to combat the challenges of $21^{\text {st }}$ century, such as population growth, climate change, pollution, declining biodiversity, quantity and quality and food security compelled 


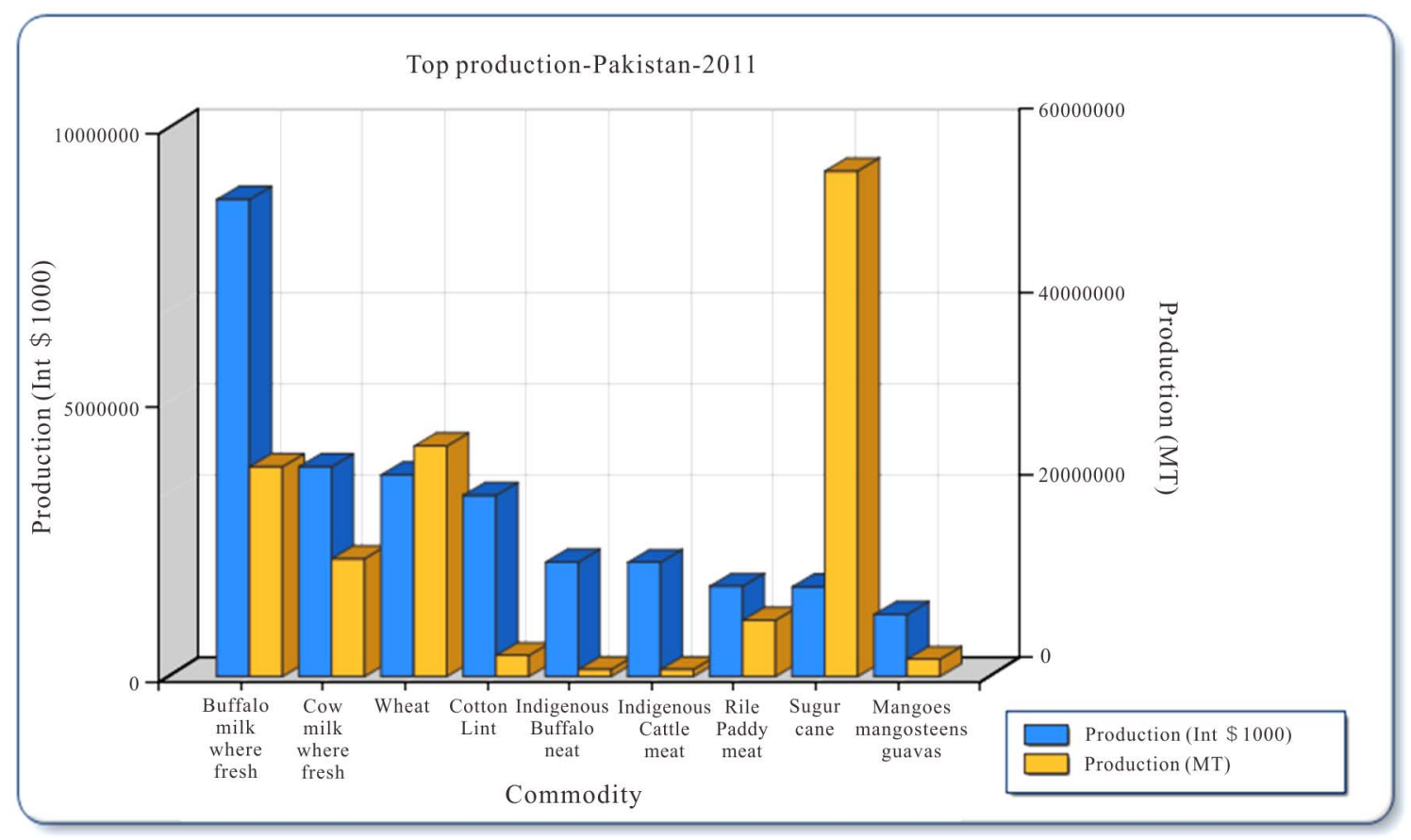

the judicious management of natural resources [6,7]. The rise in essential commodity prices since 2008 has boosted the food insecurity, poverty and law and order situation in developing countries particularly in Pakistan [811].

Among field cereal crops, the wheat has pride of place. Wheat, being the staple food of the nation demands an extra attention; it occupies a prime position in of daily food consumption of Pakistani nation [12]. By any reckoning, wheat is obligatory to combat hunger and sustain food security in Pakistan as well as developing countries. It is predicted that an increase in wheat price will help out and may wake up passion to grow more food for nation survival but it will affect the urban people who are sole buyer of wheat $[13,14]$. It is also true that world food security is threatened by increasing food demand and reduction in agricultural water availability [15]. Along with food security the fine quality of wheat is also affected by environmental stress [16-18]. A precondition for the selection of efficient and viable combinations, an extra genetic variability is need of hour. [5,19] also reported the similar genotypic variability in wheat under water stress environments. The objective of study was to evaluate an indigenous wheat germplasm under different climatic conditions to draw a line of action for the researchers to combat water stress prevailing in developing countries like Pakistan and to measure the adverse effect of water stress on growth, yield and yield contributing traits because wheat crop stands and yield components are interrelated [20]. The present study was also conducted with the aim to find out the genetic variability, heritability and selection criteria for the development of high yielding genotypes best suited to moisture stress conditions [21].

\section{Materials and Methods}

The experimental material used was comprised of seven locally developed wheat genotypes which were sown under two set of experiments under normal irrigation and water stress conditions (simulated by totally withholding irrigation after sowing) in University College of Agriculture, University of Sargodha, Pakistan during the year 2010-11. The fertility level of the field was maintained however, a buffer zone of 1.5 meter was left between the both experiments to check the seepage effects. During the whole period of experiment the agronomic practices, i.e. hoeing, weeding and fertilization etc were maintained as constant for both experiments. However the save irrigation was applied only to the normal irrigation experimental plot. The ten representative plants were selected randomly to collect the data. The data thus collected were analyzed using descriptive statistical approach as described by [22].

\section{Results and Discussion}

The seven wheat genotypes were selected randomly for conventional comparison against water stress tolerance. The genotypes were evaluated for physiological and yield contributing traits. Some genotypes tend to more decline in all trait while some have tolerated the change in climate by putting minimum effects on grain yield and 
some genotypes response to moisture stress was very miserable. The mean values under normal irrigation as well as water stress condition are depicted in Table 1.

\subsection{Plant Height}

The role of climate change has inserted negative effects, by showing decline in most of the yield contributing traits which ultimately decreased grain yield of genotypes.

The genotypic percent decline has been shown in Table 1 under both moisture conditions which depicts that the genotypes Shahkar attained plant height was decreased maximum, that was up to 18.07 percent while the genotype $\mathrm{C}-518$ showed minimum decrease i.e. 7.55 percent due to the action of moisture stress. The Figure 1 showed varietal difference in wheat yield when all the other factors regarding fertility level, provision of fertilizer remained constant. The results are in agreement of [18].

\subsection{Flag Leaf Area}

Flag leaf area has prime importance in plant growth due to its vital role in photosynthesitic activities. Genotypes having the capability to regulate its stomatal movement may survive at best level. Available moisture may definitely tolerate for longer time against stress spell and can use available moisture efficiently to convert to it in to economic yield. In present study it was noted that water stress has decreased flag leaf area significantly in almost all genotypes [23]. The post green revolution genotype Uqab-2000 was badly and reduced the flag leaf area up to $23.96 \%$ while minimum effect of climate change was

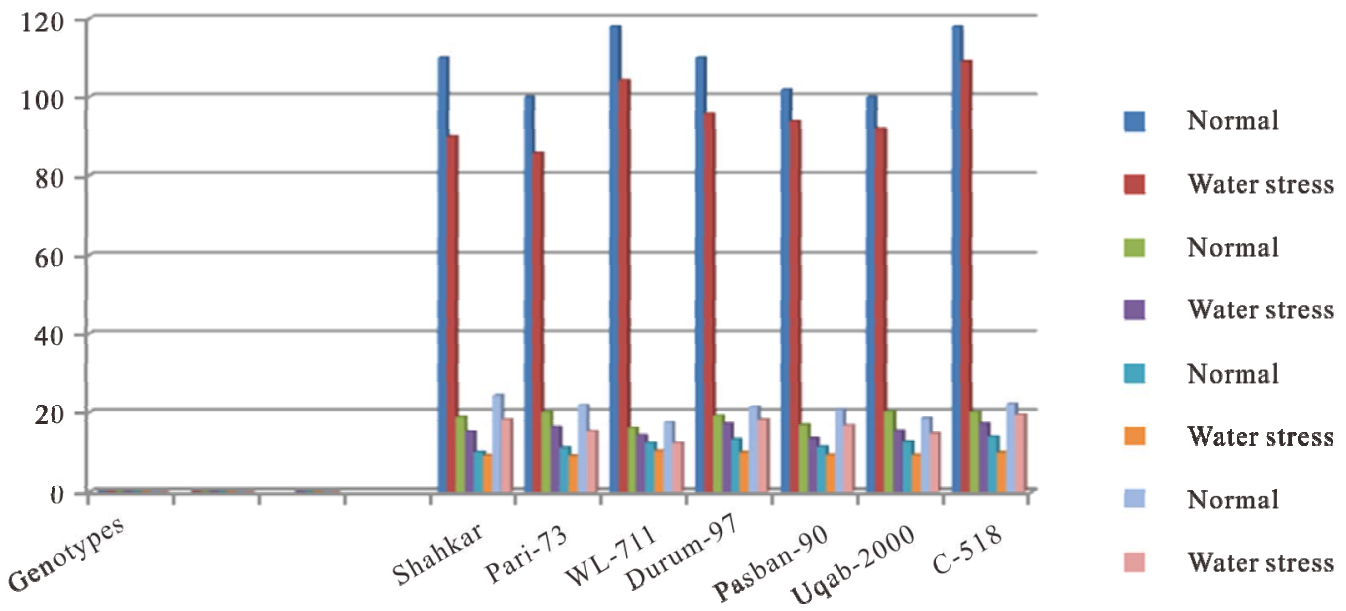

Figure 1. Varietal differences in wheat genotypes under normal and moisture Stress conditions.

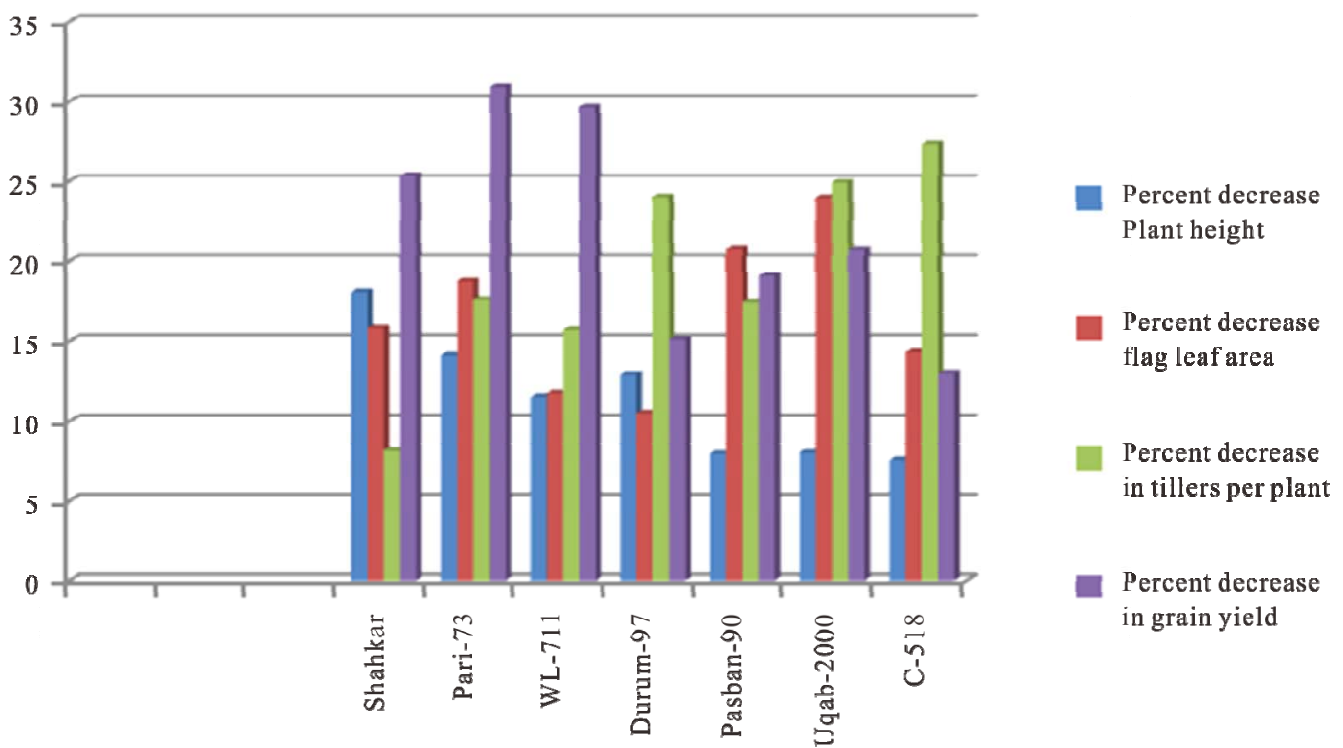

Figure 2. Percent decrease in Wheat genotypes by the action of water Stress. 
Table 1. Mean values of seven wheat genotypes under normal irrigation and water stress conditions.

\begin{tabular}{|c|c|c|c|c|c|c|c|c|c|}
\hline \multirow{3}{*}{ Genotypes } & \multicolumn{8}{|c|}{ Plant traits scored in the field study } & \multirow{3}{*}{$\begin{array}{l}\text { Percent decrease } \\
\text { in yield }\end{array}$} \\
\hline & \multicolumn{2}{|c|}{ Plant height (cm) } & \multicolumn{2}{|c|}{ Flag leaf area $\left(\mathrm{cm}^{2}\right)$} & \multicolumn{2}{|c|}{ No. of tillers/plant } & \multicolumn{2}{|c|}{ Grain yield (g) } & \\
\hline & Normal & Water stress & Normal & Water stress & Normal & Water stress & Normal & Water stress & \\
\hline Shahkar & 110 & 90.12 & 18.90 & 15.23 & 10.16 & 9.33 & 24.50 & 18.28 & 25.38 \\
\hline Pari-73 & 100 & 85.90 & 20.12 & 16.35 & 11.25 & 9.27 & 22.10 & 15.26 & 30.95 \\
\hline \multirow[t]{2}{*}{$\begin{array}{l}\text { WL-711 } \\
\text { Durum-97 }\end{array}$} & 118 & 104.35 & 16.18 & 14.27 & 12.36 & 10.42 & 17.55 & 14.35 & 18.23 \\
\hline & 110 & 95.78 & 19.25 & 17.22 & 13.28 & 10.09 & 21.45 & 18.21 & 15.10 \\
\hline Pasban-90 & 102 & 93.88 & 16.98 & 13.45 & 11.47 & 9.47 & 20.76 & 16.80 & 19.07 \\
\hline Uqab2000 & 100 & 91.97 & 20.24 & 15.39 & 12.64 & 9.49 & 18.58 & 14.73 & 20.72 \\
\hline C- 518 & 118 & 109.09 & 20.08 & 17.21 & 13.88 & 10.08 & 22.36 & 19.46 & 12.97 \\
\hline Mean & 108.28 & 95.87 & 18.82 & 15.59 & 12.15 & 9.73 & 20.48 & 16.73 & 20.34 \\
\hline
\end{tabular}

Percent decrease in wheat genotypes due to moisture stress condition.

denoted by Durum-97 (10.54\%). Similar results were reported by $[24,25]$.

\subsection{Number of Tillers per Plant}

The final number of ears produced is obviously the number of tillers which survive to bear ears which is surely a yield contributing trait. The tillers usually die when sufficient water dose not available to plant that is why some genotype tolerate while other sufferers badly. In the present study water stress had caused abortion of vegetative tillers and reduced the surviving tillers. [26] reported the decrease in the number of productive tillers in the genotypes under terminal drought. In this experiment the genotype C-518 was effected badly and shoed a much reduction (27.37\%) reduction. The obtained results are in line with the results of earlier reporter like [27] that number of tillers per plant was affected by moisture stress.

\subsection{Grain Yield}

Grain yield per plant is the ultimate goal of any agricultural research programme and research seeks wheat improvement exercises by increasing grain yield. In this experiment the genotypes showed a significant reduction in grain yield by this way. The genotype Shahkar showed $(25.38 \%)$ reduction in grain yield by the action of moisture stress while Pari-73 (30.95\%), Wl-711 (18.23\%), Duram-97 (15.10\%), Pasban-90 (19.07\%), Uqab-2000 (20.72\%) and C-518 (12.97\%). The minimum effect of moisture stress was shown by genotypes C-518 (12.97\%) while the genotype Pari-73 showed maximum decline percentage. Reduction in grain yield by an advent of moisture stress was reported by [18,
27-29]. The decline in growth parameters showed a decline trend towards yield.

\section{Conclusion}

The grain yield is a cumulative effect of all yield contributing traits and grain yield has prime role in selection of a genotype. Due to increasing population and degraded soil condition, change in climatic conditions, the wheat yield is effected badly. Conventional plant breeding pulled up the yield up till now to fulfill the nutritional needs of developing countries. The global change in climatic condition as well as population explosion will boost up further food shortage which may result law and order situation in the world. The use of moisture stress tolerant varieties may save the developing or threatened countries from coming havoc.

\section{REFERENCES}

[1] I. R. Noorka, "Sustainable Rural Development and Participatory Approach by On-Farm Water Management Techniques,” In: Sustainable Agricultural Development, Springer, New York, 2011, pp. 139-146. doi:10.1007/978-94-007-0519-7_9

[2] I. R. Noorka and S. A. Shahid, "Use of Conservation Tillage System in Semiarid Region to Ensure Wheat Food Security in Pakistan," Development in Soil Salinity Assessment and Reclamation, Springer Book, 2013. http://www.springer.com/environmrnt/soil+science/book/ 978978-94-007-5683-0

[3] Food and Agriculture Organization, "FAO Stat,” The Statistics Division of the FAO, 2012. http://faostat.fao.org/site/339/default.aspx

[4] A. Shafi, G. Shabbir, Z. Akram, T. Mahmood, A. Bakhsh, and I. R. Noorka, "Stability Analysis of Yield and Yield 
Components in Chickpea Genotypes across Three Rainfed Locations of Pakistan,” Pakistan Journal of Botany, Vol. 44, No 5, 2012, pp. 1705-1709.

[5] I. R. Noorka, S. Tabassum and M. Afzal, "Detection of Genotypic Variation in Response to Water Stress at Seedling Stage in Escalating Selection Intensity for Rapid Evaluation of Drought Tolerance in Wheat Breeding," Pakistan Journal of Botany, Vol. 45, No. 1, 2013, pp. 99-104.

[6] I. R. Noorka, and J. A. Teixeira da Silva, "Mechanistic Insight of Water Stress Induced Aggregation in Wheat (Triticum aestivum L.) Quality: The Protein Paradigm Shift,” Notulae Scientia Biologicae, Vol. 4, No. 4, 2012, pp. 32-38.

[7] J. Yang, R. G. Sears, B. S. Gil and G. M. Paulsen, “Genotypic Differences in Utilization of Assimilate Sources during Maturation of Wheat under Chronic Heat and Heat Shock Stresses,” Euphytica, Vol. 125, No. 2, 2002, pp. 179-188. doi:10.1023/A:1015882825112

[8] Food and Agriculture Organization (FAO), "Food Balance Sheets," 2008. http://faostat.fao.org/site/368/default.aspx

[9] Asian Development Bank (ADB), "Food Prices and Inflation in Developing Asia: Is Poverty Reduction Coming to an End?” Economic \& Research, Departmental Special Report, Asian Development Bank, Manila, 2008.

[10] Z. Haq, H. Nazli and K. Meilke, "Implications of High Food Prices for Poverty in Pakistan,” Agricultue and Economics, Vol. 39, 2008, pp. 477-484.

[11] B. J. Von, "High and Rising Food Prices: Why Are They Rising, Who Is Affected, How They Are Affected, and What Should Be Done?” International Food Policy Research Institute (IFPRI), 2008. http://www.ifpri.org/presentations/20080411jvbfoodprice s.pdf

[12] I. R. Noorka, A. Batool, S. AlSultan, S. Tabasum and A. Ali, "Water Stress Tolerance, Its Relationship to Stem Reserve Mobilization and Potence Ratio in Spring Wheat," American Journal of Plant Sciences, Vol. 4, No 2, 2013, pp. 231-237. doi:10.4236/ajps.2013.42030

[13] Government of Pakistan, "Economic Survey of Pakistan," Finance Division, Economic Advisory Wing, Islamabad. 2011.

[14] Z. U. Haq, H. Nazli, K. Meilke, M. Ishaq, A. Khattak, A. H. Hashmi and F. U. Rehman, "Food Demand Patterns in Pakistani Punjab,” Sarhad Journal of Agriculture, Vol. 27, No. 2, 2011, pp. 305-311.

[15] S. J. Zwart and W. G. M. Bastiaanssen, "Review of Measured Crop Water Productivity Values for Irrigated Wheat, Rice, Cotton and Maize," Agriculture and Water Management, Vol. 69, No. 2, 2004, pp. 115-133. doi:10.1016/j.agwat.2004.04.007

[16] M. Ahmad and M. A. Arain, "Effect of Drought Simulation on Grain Weight, Protein and Lysine Content of Bread Wheat,” Pakistan Journal of Botany, Vol. 31, No. 1, 1999, pp. 109-114.

[17] J. G. Mary, J. C. Stark, K. O. Brien and E. Souza, "Relative Sensitivity of Spring Wheat Grain Yield and Quality
Parameters of Moisture Deficit," Crop Science, Vol. 41, No. 2, 2001, pp. 327-335. doi:10.2135/cropsci2001.412327x

[18] I. R. Noorka, S. Rehman, J. R. Haidry, I. Khaliq, S. Tabassam and M. Din, "Effect of Water Stress on PhysicoChemical Properties of Wheat (Triticum aestivum L.)," Pakistan Journal of Botany, Vol. 41, No. 6, 2009, pp. 2917-2924.

[19] I. R. Noorka, I. Khaliq and M. Kashif, "Index of Transmissibility and Genetic Variation in Spring Wheat Seedlings under Water Deficit Conditions,” Pakistan Journal of Agricultural Sciences, Vol. 44, No. 4, 2007, pp. 604607.

[20] Y. Zhen-Wen, D. A. Van Sanford and D. B. Egli, "Effect of Population Density on Floret Initiation, Development and Abortion in Winter Wheat," Annals of Botany, Vol. 62, 1988, pp. 295-302.

[21] B. Ehdaie and J. G. Waines, "Genetic Variation, Heritability and Path-Analysis in Landraces of Bread Wheat from South Western, Iran,” Euphytica, Vol. 41, 1989, pp. 183-190.

[22] M. K. Trochim William, “Descriptive Statistics,” Research Methods Knowledge Base, 2006 http://www.socialresearchmethods.net/kb/statdesc.php

[23] A. O. Anyia and H. Herzog, "Water Use Efficiency, Leaf Area and Leaf Gas Exchange of Cowpeas under MidSeason Drought," Europian Journal of Agronomy, Vol. 20, No. 4, 2004, pp. 327-339. doi:10.1016/S1161-0301(03)00038-8

[24] R. H. Kazmi, M. Q. Khan and M. K. Abbasi, "Yield and Yield Components of Wheat Subjected to Water Stress under Rainfed Conditions,” Acta Agronomica Hungarica, Vol. 51, No. 3, 2003, pp. 315-323 doi:10.1556/AAgr.51.2003.3.9

[25] N. K. Blake, S. P. Lanning, J. M. Martin, J. D. Sherman and L. E. Talbert, "Relationship of Flag Leaf Characteristics to Economically Important Traits in Two Spring Wheat Crosses," Crop Science, Vol. 47, No. 2, 2007, pp. 491494. doi:10.2135/cropsci2006.05.0286

[26] D. L. Keim, “Adaptation of Winter Wheat Cultivars to Dry Land Conditions and Their Response to Water Stress," Ph.D. Thesis, Oregon State University, Corvallis Oreg, 1974, p. 155.

[27] A. R. Nabipour, B. Yazdi-Samadi, A. A. Zali and K. Poustini, "Effects of Morphological Traits and Their Relations to Stress Susceptibility Index in Several Wheat Genotypes,” BIBAN, Vol. 7, No. 1, 2002, pp. 31-47.

[28] R. K. Hassaan, "Effect of Drought Stress and Yield Components of Some Wheat and Triticale Genotypes,” Annals of Agriculture Sciences, Vol. 48, No. 1, 2003, pp. 117129.

[29] G. M. Laghari, F. C. Oad, S. Tunio, Q. Chachar, A. W. Ghandahi, M. H. Siddiqui, S. W. Hassan and A. Ali, "Growth and Yield Attributes of Wheat at Different Seed Rates,” Sarhad Journal of Agriculture, Vol. 27, No. 2, 2010, pp. 177-183. 